\title{
PENGARUH KEPEMIMPINAN, BUDAYA ORGANISASI, DAN IKLIM ORGANISASI TERHADAP TATA KELOLA PROGRAM STUDI PERGURUAN TINGGI SWASTA DI KOTA PEKANBARU PROVINSI RIAU
}

\author{
EFFECT OF LEADERSHIP, ORGANIZATIONAL CULTURE, AND \\ ORGANIZATIONAL CLIMATE ON STUDY PROGRAM GOVERNANCE PRIVATE \\ HIGHER EDUCATION IN PEKANBARU CITY OF RIAU PROVINCE
}

\author{
Zulkifli \\ Program Studi Magister Manajemen, Program Pascasarjana, Universitas Riau Kepulauan \\ zulkifli@yahoo.com
}

\begin{abstract}
Abstrak
Tujuan dari penelitian ini adalah untuk mempelajari pengaruh kepemimpinan, budaya organisasi dan iklim organisasi terhadap program tata kelola perguruan tinggi di sektor swasta di Kota Pekanbaru, Provinsi Riau. Penelitian ini menggunakan pendekatan kuantitatif dengan metode survei dan teknik analisis jalur. Data dikumpulkan dari 251 dosen sebagai responden dalam 109 sampel program studi. Finding Show: kepemimpinan memiliki efek langsung positif terhadap tata kelola, nilai t-statistik 3,26> 1,64 atau nilai sig 0,00 $<0,05$, dan nilai koefisien jalur (p) 0,15, (2) budaya organisasi memiliki pengaruh langsung positif terhadap tata kelola, nilai t-statistik dari 6,99> 1,64 atau nilai sig 0,00 <0,05, dan nilai koefisien jalur (p) 0,48, (3) iklim organisasi memiliki pengaruh langsung positif terhadap tata kelola, nilai $t$-statistic 3,79> 1,64 atau nilai sig $0,00<0,05$, dan nilai koefisien jalur (p) 0,26, (4) kepemimpinan memiliki efek langsung positif terhadap iklim organisasi, nilai t-statistik 2,86> 1, 64 atau nilai sig 0,00<0,05, dan nilai koefisien jalur (p) 0,12, dan (5) budaya organisasi berpengaruh langsung positif terhadap iklim organisasi, nilai t-statistik 18,85> 1,64 atau nilai sig 0, 00 <0,05, dan nilai koefisien jalur (p) 0,77. Tata pemerintahan dengan meningkatkan kepemimpinan, budaya organisasi dan terus meningkatkan. iklim organisasi.
\end{abstract}

Kata kunci: Kepemimpinan, Budaya Organisasi, Iklim Organisasi, Program Studi Pemerintahan

\begin{abstract}
The goal of this research is to empirically study the effect of leadership, organizational culture and organizational climate toward study program governance of college private sector in Pekanbaru City, Riau Province.The research used quantitave approach with survey method and path analysis technique. Data was collected from 251 lecturers as respondence in 109 study program sample. Finding Show: leadership has positive direct effect toward governance, value of t-statistic of 3.26>1,64 or sig value 0,00<0,05, and path coefficient value (p) 0.15, (2) organizational culture has positive direct effect toward governance, value of tstatistic of 6.99>1,64 or sig value 0,00<0,05, and path coefficient value (p) 0.48, (3) organizational climate has positive direct effect toward governance, value of t-statistic of $3.79>1,64$ or sig value $0,00<0,05$, and path coefficient value (p) 0.26,(4) leadership has positive direct effect toward organizational climate, value of $t$ statistic of 2.86>1,64 or sig value 0,00 <0,05, and path coefficient value (p) 0.12, and (5) organizational culture has positive direct effect toward organizational climate, value of t-statistic of 18.85>1,64 or sig value 0,00 $<0,05$, and path coefficient value (p) 0.77.The findings lead to implication to increase study program governance by improving leadership, organizational culture and continuously improve organizational climate.
\end{abstract}

Key words: Leadership, Organizational Culture, Organizational Climate, Governance Study Program 


\section{PENDAHULUAN}

Keberhasilan perguruan tinggi secara langsung ditentukan oleh kualitas pendidikan dan penelitian dan bukan oleh kualitas manajemennya. Namun demikian, kelemahan dalam proses manajemen dapat mengakibatkan penurunan kualitas pendidikan dan penelitian. Dalam rangka mengarahkan dan mengendalikan organisasi untuk mencapai tujuan yang optimal, beberapa program studi perguruan tinggi swasta di Kota Pekanbaru belum sepenuhnya menerapkan best practicetata kelola (governance) yang baik, yaitu; (1) pemilik perguruan tinggi menjabat sebagai pengelola, (2) tugas pokok dan fungsi Ketua Program Studi tidak dituangkan dalam bentuk ketentuan formal, (3) tidak ada agenda pertemuan berkala yang membahas tentang perkembangan dan permasalahan yang dihadapi program studi, (4) para dosen tetap merangkap jabatan sebagai staf administrasi, dan melakukan pekerjaan klerikal kesektrariatan,dan (5) laporan kinerja pertanggung jawaban berkala program studi yang menginformasikan tentang pengukuran kinerja sesuai dengan indikator kinerja yang ditetapkan dalam Rencana Stratejik belum dibuat secara formal.Selain itu,dari 150 program studi, peringkat akreditasi A hanya sebanyak 16 program studi atau 10,67\%, peringkat B sebanyak 43 program studi atau 28,67\%, dan sisanya sebanyak 91 program studi atau $60,66 \%$ peringkat $\mathrm{C}$.

Menurut BAN-PT (2008:6) implementasi tata kelola yang baikdicerminkan dari baiknya sistem pengelolaan fungsional program studi. Lebih jauh Indrajit dan Pranoto (2006:286) menyatakan bahwa tata kelola program studi yang baik juga dicerminkan dari keterpisahan penyelenggaran dan pemilik. Selain itu, dalam memenuhi standar nasional pendidikan pengelolaan sistem pendidikan dilaksanakan secara mandiri, efisien, efektif dan akuntabel (SNP: 2005). Tata kelola (governance) menurut OECD (2004) adalah "procedures and proceses according to wich an organization is directed and controlled".

Pada hubungan tata kelola perguruan tinggi, Shattock (2006) mendefinisikan tata kelola universitas, "as the constitutional forms and processes through which universities govern their affairs”.Kepemimpinan sebagaimana di kemukakan Yukl (2010) adalah refleksi dari asumsi-asumsi yang mencakup suatu proses, dimana pengaruh secara sengaja digunakan kepada orang lain untuk mengarahkan, menbentuk dan memfasilitasi aktivitas-aktivitas dan hubungan dalam kelompok organisasi. Selanjutnya, budaya organisasi menurut McShane (2008) berisikan nilai-nilai dan asumsi- asumsi bersama di dalam organisasi, yang menggambarkan apa yang dianggap penting dan yang tidak penting didalam suatu 
organisasi, dan secara konsekuen mengarahkan seseorang melakukan hal-hal yang benar kedepan, sedangkan iklim organisasi menurut Sparrow (2001) dimaknai sebagai pesan yang diterima oleh anggota dan persepsi bersama atas kebijakan, pelaksanaan dan prosedur organisasi.

Tantangan globalisasi, pemerintah dalam Undang-Undang No. 12 tahun 2012 tentang Pendidikan Tinggi, Pasal 50 memberi peluang bagi perguruan tinggi asing yang ingin melakukan kerja sama dengan perguruan tinggi di Indonesia. Artinya, Indonesia harus membuka diri seluas-luasnya terhadap masuknya perguruan tinggi, dosen, dan peneliti asing dalam batasan-batasan tertentu.

Dalam rangka mengarahkan dan mengendalikan organisasi dirumuskan indikator tata kelola, yakni transparansi, yaitu arus bebas informasi, pemrosesan dan informasi harus dapat secara langsung diakses oleh pihak yang berkepentingan, (2) tanggung jawab, dimana pengambil keputusan harus mempertanggungjawabkan kepada publik sebagaimana organisasi mempertanggung jawabkan kepada pihak-pihak yang berkepentingan, (3) keadilan (fairness), adanya perlakuan yang setara terhadap semua pihak yang berkepentingan sesuai dengan kriteria dan proporsi yang seharusnya, (4) kebijakan, yaitu ketentuan pokok yang menjadi dasar dan arah dalam melaksanakan pengelolaan, (5) kemandirian (independen), korporasi harus bebas dari pengaruh-pengaruh pemerintah serta tekanan pihak lainnya yang tidak sesuai dengan mekanisme koroprasi, dan (6)partisipasi, dimana keterlibatan mental dan emosional orang-orang dalam siatuasi kelompok yang mendorong mereka untuk memberikan kontribusi kepada tujuan organisasi dan berbagi tanggung jawab dalam pencapaian tujuan.

Indikator-indikator tata kelola merupakan pilar-pilar yang akan menyangga suatu bangunan tata kelola yang baik (good corporate governance) suatu organisasi, dan suatu bangunan akan berdiri kokoh dan megah didasari pada suatu pondasi yang kuat. Pondasi tata kelola, sebagaimana yang terungkap dalam elemen penilaian program studi oleh BAN-PT (2008), antara lain kepemimpinan yang kuat dan efektif, dan budaya organisasi yang kuat. Selain itu, McMurray (2012) menyatakan iklim organisasi mengacu pada persepsi bersama terhadap kebijakan, pelaksanaan dan prosedur organisasi, baik secara formal maupun informal.

International Food and Agriculture Development (IFAD) (2005) menyatakan, "governance for sustainable human development. The document state that governance can be seen as the exercise of economic, political and administrative authority to manage country's 
affair at all levels”. Menurut definisi ini, tata kelola yang baik memiliki tiga kaki, yaitu: ekonomi, politik, dan administratif.

Berdasarkan pendapat para ahli, dan menghindari risiko kebiasan dalam pengukuran varibel ekonomi, politik, dan administrasi, dirumuskan model konstelasi bangunan tata kelola pada Gambar 1 berikut:

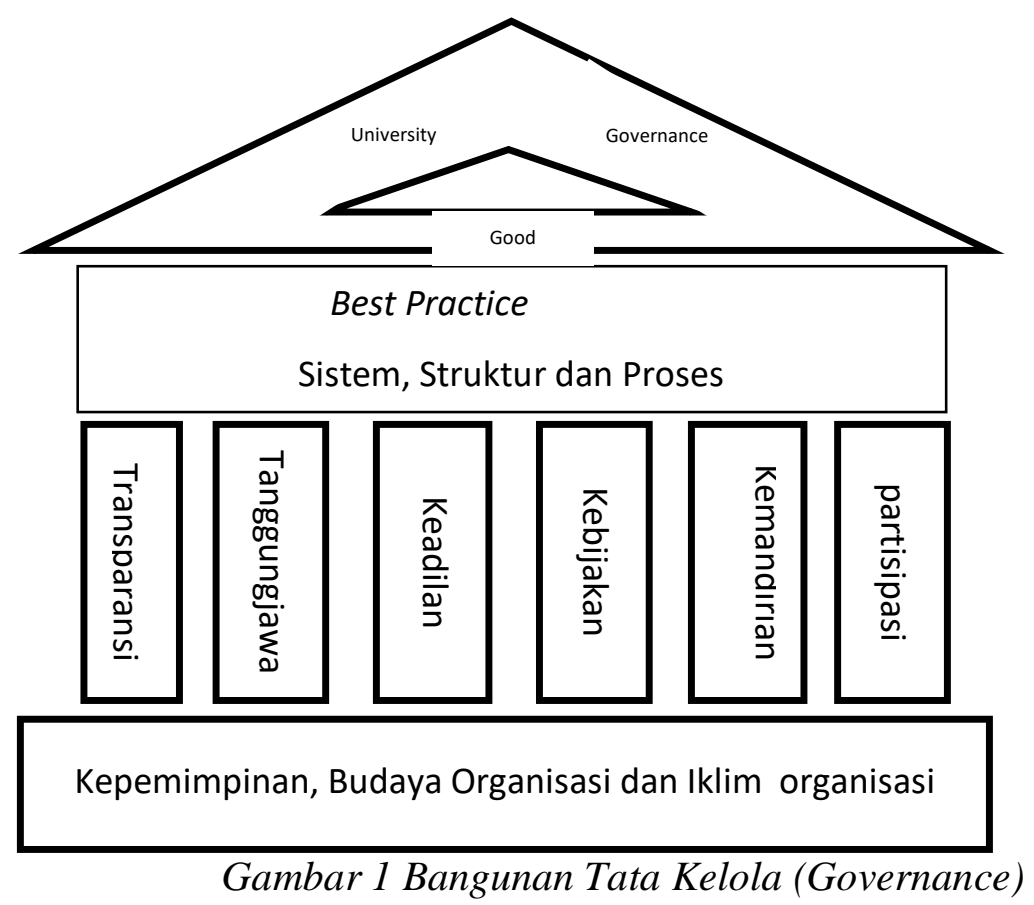

Sumber: Ilustrasi Peneliti, 2018

Berdasarkan konstelasi bangunan tata kelola diatas, dirumuskan masalah penelitian, sebagai berikut; (1) apakah terdapat pengaruh langsung kepemimpinan terhadap tata kelola? (2) apakah terdapat pengaruh langsung budaya organisasi terhadap tata kelola? (3) apakah terdapat pengaruh langsung iklim organisasi terhadap tata kelola? (4) apakah terdapat pengaruh langsung kepemimpinan terhadap iklim organisasi? dan (5) apakah terdapat pengaruh langsung budaya organisasi terhadap iklim organisasi?

\section{Kajian Teoritik}

\section{Tata Kelola}

Menurut Sutojo dan Aldridge (2005) kata governance berasal dari bahasa Perancis gubernance yang berarti pengendalian, sedangkan Governancemenurut Indrajit dan Pranoto (2006) dapat diterjemahkan dalam bahasa Indonesia sebagai tata kelola. 
Negara-negara maju di Eropa, Amerika dan Asia Timur yang tergabung dalam Organisation For Economic Co-Operation and Development (OECD), mendefinisikan tata kelola, "governance isprocedures and processes according to wich an organization is directed and controlled". Dalam pengendalian dan pengarahan organisasi ditetapkan prinsip tata kelola, antara lain (a) suatu kerangka kerja tata kelola harus dapat menggambarkan transparansi dan pasar yang efisien, (b) konsisten dengan peraturan perundang-undangan, (c) mempunyai makna yang jelas dalam pembagian tanggung jawab diantara perbedaan pengawasan, peraturan dan penegakan otoritas atau kewenangan, (d) memastikan kesetaraan perlakuan kepada seluruh pemilik, dan (e) memastikan bahwa pengungkapan yang tepat waktu dan akurat dinyatakan dalam keseluruhan hal-hal mengenai organisasi. Edward (2005) berpandangan yang sama dengan OECD, tata kelola adalah, "about how an organization steers itself and processes and structures used to achieve its goals”. Pengertian ini di perkuat oleh pendapat Sutedi (2012), yang menyatakan good corporate governance merupakan sistem yang mengatur dan mengendalikan korporasi untuk menciptakan nilai tambah (added value) bagi semua stakeholders, dan dalam tata kelola diperlukan empat komponen utama, yaitu (1) fairness, (2) transparency, (3) accountability, dan (4) responsibility.

Lebih jauh The United Nations Development Programme (UNDP) dalam International Fund For Agriculture Development (IFAD) (2005) mengungkapkan” Good governance comprise the existence of effective mechanisms, processes and institutions through which citizens and groups articulate their interest, exercise then legal rigfhts, meet their obligations and mediate their differences”, yang meliputi indikator penting, yaitu, (1) participation,(2) rule of law, (3) transparency, (4) responsiveness, (5) consensus orientation,(6) equity, (7) effectiveness and efficiency, (8) accountability, and (9) strategic vision.

Dalam mengukur keberhasilan pelaksanaan tata kelola, National Commission on Human Right (2000) menetapkan indikator, sebagai berikut: "first, fairness, second, transparency, third, accountability, andfourth, responsibility”.Khusus terhadap tata kelola universitas, Shattock (2006) mendefinisikan tata kelola, "as the constitutional forms and processes through which universities govern their affairs.Dalam pengertian ini, perlakuan tata kelola sebagai perkembangan yang benar adalah melalui organ institusi dalam sebuah kepengurusan, yang kemudian diturunkan melalui senat dengan badan akademik kepada pengurus fakultas dan dalam pertemuan-pertemuan antar fakultas dan bagian lainnya. Lebih jauh, pandangan Shattock menegaskan bahwa tata kelola merupakan kesepakatan- 
kesepakatan yang dibuat oleh para stakeholder dan dituangkan dalam suatu bentuk ketentuanketentuan tertulis yang akan menjadi pedoman dalam rangka pencapaian stratejik organisasi.

Tata kelola manajemen yang baik memastikan bahwa tata kelola pada semua tingkat dalam institusi berjalan dengan baik, kesemuanya menghubungkan bagian-bagian yang tersambung dengan mulus, dan proses itu menggabungkan kepada pengiriman untuk sebuah budaya organisasi yang sempurna dan fleksibel. Menurut Eurydice (2008), "governance refers tothe formal and informal exercise of authority unders laws, policies and rules that articulate the rights and responsibilities of various actors, including the rules by they interact”.

Model penerapan tata kelola di Indonesia pada pokoknya mengacu pada format Badan Akreditasi Nasional Perguruan Tinggi (BAN-PT) selaku badan yang bertugas dalam pengedalian pendidikan tinggi.BAN-PT mendefinisikan tata pamong (governance) sebagai sistem untuk memelihara efektivitas peran para konstituen dalam pengembangan kebijakan, pengambilan keputusan, dan penyelenggaraan program studi. Dalam rangka pengimplementasian dan pengendalian tata pamong, ditetapkan lima kriteria yang berfungsi sebagai alat ukur atau indikator, yaitu (1) kredibilitas, (2) transparansi, (3) akuntabilitas, (4) tanggungjawab dan (5) adil.Tata pamong didukung dengan penetapan dan penegakan sistem nilai dan norma, serta dukungan institusi perguruan tinggi, dosen, mahasiswa, tenaga kependidikan dan stakeholders. Dari aspek fungsional, tata kelola yang baik dapat ditinjau dari sisi apakah tata kelola telah berfungsi secara efektif dan efisien dalam upaya mencapai tujuan yang telah ditetapkan. United National Development Project (UNDP) dalam IFAD (2005) menyatakan, "governance for sustainable human development. The document state that governance can be seen as the exercise of economic, political and administrative authority to manage country's affair at all levels”. Menurut definisi ini, tata kelola yang baik memiliki tiga kaki, yaitu: ekonomi, politik, dan administratif.

Sutedi (2012) menyatakan, dalam perekonomian modern, manajemen, dan pengelolaan korporasi semakin banyak dipisahkan dari kepemilikan korporasi. Hal ini sejalan dengan Agency Theory yang menekankan pentingnya pemilik korporasi menyerahkan kepada tenaga professional yang lebih mengerti dalam menjalankan usaha seharihari.Keterpisahan kepemilikan dengan pengelola juga diungkapkan Indrajit Pranoto (2006) yang menyatakan bahwa tata kelola program studi yang baik dicerminkan dari keterpisahan penyelenggara dan pemilik, dan Trole dalam Prasetyantoko (2012) yang mengungkapkan 
bahwa pemahaman standar tentang corporate governance berbasis pada prinsip pemisahan kepemilikan dengan pengelolaan.

Dari berbagai deskripsi konsep tata kelola, tata kelola (governance) pada pokoknya disentesiskan sebagai prosedur dan proses yang mengarahkan dan mengendalikan organisasi, yang dituangkan dalam bentuk ketentuan tertulis melalui proses hubungan antara para pengurus dalam tata kelola guna untuk pencapaian stratejik organisasi secara optimal, dengan indikator, yakni (1) transparansi, (2) tanggung jawab, (3) keadilan (fairness, (4) kebijakan, (5) kemandirian (independen), dan (6)partisipasi.

\section{Kepemimpinan}

Kesuksesan atau kegagalan organisasi dipengaruhi oleh pemimpinnya. Ada konsep yang menghubungkan antara pemimpin dengan keterwujudan visi, keterlaksanaan misi dan ketercapaian tujuan organisasi. Namun demikian, faktor situasi, budaya organisasi, anutan nilai anggota organisasi juga mempengaruhi efektifivitas pengelolaan suatu organisasi. Para ahli mendefinisikan kepemimpinan dengan cara yang berbeda-beda. Nelson and Campbel (2006) mendefinisikan "Leadership in organization is the process of guiding and directing the behavior of people in the work environment".Kepemimpinan juga didefinisikan oleh Gibson, et,al (2002) sebagai “an interaction between members of group”,dan Slocum (2009) yang pada dasarnya menyatakan bahwa kepemimpinan adalah proses pengembangan ide dan visi, hidup dalam nilai-nilai yang didukung oleh ide dan visi para anggota, dan mempengaruhi yang lain dan perilaku yang dimiliki pemimpin serta mengambil keputusan bersama tentang manusia dan sumberdaya lainnya. Mc Shane dan Glinow (2008), lebih jauh menyatakan kepemimpinan adalah tentang mempengaruhi, memotivasi, dan memungkinkan yang lain untuk memberikan kontribusi kedepan dalam rangka untuk mencapai kesuksesan keefektifitasan organisasi. Hal ini diperkuat oleh Achua dan Robert (2010) yang mendefinisikan” leadership is the influencing process of leaders and followers to achieve organizations objectives through change”.

Berbagai definisi para ahli tentang kepemimpinan diatas, mengisyaratkan bahwa kepemimpinan memiliki dua dimensi, yakni (1) dimensi skill dan pengaruh dari pemimpin, dan (2) dimensi hubungan kebersamaan timbal balik dalam mencapai tujuan organisasi. Hal ini diperkuat dengan pendapat Daft (2010) yang menyatakan, "leadership as defined is the ability to influence people toward the attainment of goals”. 
Pada dasarnya seluruh definisi kepemimpinan memiliki substansi yang sama meskipun dari pandang yang berbeda. Yukl (2010) mengajukan 10 (sepuluh) definisi kepemimpinan,yangmengandung tiga unsur utama, yakni (1) kemampuan memimpin,(2) proses mempengaruhi orang lain, dan (3) tujuan organisasi.

Sebagai sebuah proses, kepemimpinan adalah proses penggunaan pengaruh untuk memperjelas tujuan organisasi bagi para staf atau yang dipimpinnya. Proses ini memerlukan kemampuan untuk memotivasi serta membantu staf untuk mengadopsi dan menata kelola budaya produktif organisasi. Sebagai atribut, kepemimpinan adalah kumpulan karakteristik yang harus dimiliki oleh seseorang. Kepemilikan atribut dimaksudkan menjadi faktor penentu keberhasilan seorang pemimpin.Pemimpin dapat menggerakkan komponen organisasi atas kepemilkian visi. Visi tersebut tanpak pada karakter dan perilaku pemimpin.

Dalam pandangan lain Nelson (2006) membagi teori kepemimpinan yang terdiri:” (1) trait theories, (2) behavioral theories, and (3) contingency theories”.Teori sifat diasosiasikan dengan bentuk fisik dan non fisik yang dimilki seorang pemimpin. Teori perilaku yang diidentifikasi oleh Lewin dengan para mahasiswanya menemukan 3 (tiga) jenis gaya kepemimpinan, yakni (1) autokratik, (2) demokratik, dan (3) laiisez-faire. Teori kontijensi berhubungan dengan pendapat dan model (1) Fiedlers Contingency Theory, (2) Path-Goal Theory, (3) Normative Decision Theory, dan (4) Situasional Leadership Theory.

Berbagai konseptual, khususnya perilaku kepemimpinan pendekatan kontijensi atau kemungkinan pada dasarnya berlandaskan pendekatan pada orang, tugas dan situasi. Hal ini diperkuat oleh Gibson, et.al (2002), dimana pada tahun 1947 Rensis Linkert memulai penelitian tentang, "how best to manage the efforts of individuals to achieve desire production and satisfaction objectives”. Selajutnya melalui interview kepada para pemimpin dan pengikut, Rensis Linkert menemukan 2 (dua) gaya kepemimpinan yang berbeda, yaitu yang berpusat pada pekerjaan dan yang berpusat pada karyawan.

Kepemimpinan pada pokoknya adalah upaya mempengaruhi orang lain dalam pencapaian tujuan organisasi. Hal ini diperkuat oleh pendapat Wirawan (2003) yang menyatakan esensi kepemimpinan adalah aktivitas mempengaruhi. Selanjutnya mempengaruhi adalah proses dimana orang yang mempengaruhi (Agen) berusaha merubah sikap, perilaku, nilai-nilai, norma-norma, kepercayaan, pikiran dan tujuan orang yang dipengaruhi secara sistematis. Dalam proses mempengaruhi, antara lain meliputi unsur kuasa (power). Kuasa sangat penting bagi kepemimpinan, sehingga sejumlah ahli mendefinisikan 
kepemimpinan dalam pengertian kuasa, misalnya Burns dalam Wirawan (2003) yang menyatakan "to understand the nature of leadership requires understanding of the essence of power, for leadership is special form of power", dan Daft (2005) yang mendefinisikan "power is ability of one person or departemen in an organization to influence to others people to bring about desired outcomes”. Dalam mempengaruhi orang lain terdapat lima tipe kekuasaan pemimpin, yaitu (1) legitimate power, (2) reward power, (3) coercive power, (4) expert power, and (5) referent power.

Pada dasarnya dari berbagai pendapat ahli diatas tentang kepemimpinan dapat disimpulkan bahwa pemimpin dalam mengambil keputusan, dan mengarahkan dan mengendalikan para bawahan berdasarkan pendekatan kepada orang, tugas dan situasi. Pendekatan gaya kepemimpinan yang sesuai untuk di implementasikan pada program studi adalah berdasarkan orang dan tugas melalui kuasa (power) dalam bentuk pendekatan personal power dan position power, serta memperhatikan faktor situasional yang paling memungkinkan dalam pencapaian tujuan program studi.

Dari berbagai deskripsi konsep yang dikemukakan oleh para ahli, dapat disintesiskan bahwa kepemimpinan adalah seni mempengaruhi orang lain melalui kuasa untuk mencapai tujuan organisasi, dengan indikator; (1) kepribadian, (2) kompetensi, (3) pendelegasian wewenang, (4) memberikan arahan pencapaian tujuan, (5) memberikan dukungan, (6) mengambil keputusan, (7) memberikan imbalan, (8) memberikan sanksi, (9) pemberian penghargaan, dan (10) keteladanan.

\section{Budaya Organisasi}

Kata kebudayaan berasal dari kata Sanskerta buddhayah, yaitu jamak dari buddhi yang berarti "budi” atau "akal”. Dengan demikian ke-budaya-an dapat diartikan: "hal-hal yang bersangkutan dengan akal”. Ada sarjana lain yang mengupas kata budaya sebagai suatuperkembangan majemuk dari budi-daya, yang berarti “daya dari budi”. Karena itu mereka membedakan “budaya” dari “ kebudayaan” . Dengan demikian, “budaya’ adalah “daya dari budi” yang berupa cipta, karsa dan rasa, sedangkan "kebudayaan” adalah hasil dari cipta, karsa dan rasa.

Slocum (2009) yang mendefinisikan budaya organisasi, "reflect the share and learned values, beliefs, and attitudes of its members". Lebih khusus, budaya organisasi mencakup (1) komunikasi rutin, seperti seremonial dan ritual organisasi dan bahasa umum yang digunakan, (2) norma bersama oleh individu dan tim yang ditampakkan keluar 
organisasi, (3) nilai dominan yang dianut organisasi, seperti kualitas produk dan pelayanan pada pelanggan, (4) filosofi yang memandu kebijakan manajemen dalam pengambilan keputusan, termasuk penentuan kelompok mana yang dimasukkan dalam pengambilan keputusan, (5) aturan-aturan permainan untuk mendapatkan organisasi yang bertahan dalam jangka panjang, dan (6) perasaan atau iklim yang disampaikan di dalam organisasi oleh letak bentuk fisik dimana para karyawan dan pelanggan, supplier dan pihak luar lainnya melakukan interaksi. Disi lain Schermerhon (2010) mendefinisikan, budaya organisasi adalah, "what one sees and hears when walkingaround an organization as a visitor, a costumer, or an employee".

Robbins (2011) menjelaskan bahwa budaya organisasi, "refers to a system of shared meaning held by members that distinguishes the organization from others organizations", yang dibangun oleh 7 (tujuh) karakteristik sebagai sari (essence) dari budaya organisasi, yakni:(1) Innovation and risk taking, (2) Attention to detail, (3) Outcome orientation, (4) people orientation, (5) Team orientation,(6) Aggresiveness, dan (7) Stability. Berdasarkan berbagai asumsi tersebut, hal penting yang perlu ada dalam definisi budaya organisasi adalah suatu sistem nilai-nilai yang dirasakan dan maknanya dipikirkan oleh seluruh organ dalam organisasi.

Selain pengertian budaya organisasi yang telah disebutkan diatas, terdapat pengertian budaya kepada pola. Schein dalam Moeljono (2005) mendefinisikan budaya sebagai, suatu pola asumsi dasar yang dimiliki bersama oleh kelompok ketika memecahkan masalah penyesuaian eksternal dan integrasi internal. Pola yang berhasil dan dianggap sah cenderung akan diajarkan kepada anggota baru sebagai cara yang tepat menerima, berpikir, dan merasa berhubungan dengan masalah tersebut. Peryataan lain dikemukakan oleh Nelson (2006), budaya organisasi adalah: "a pattern of basic assumptions that are considered valid and that are taught to new members as the way to perceive, think, and fell in the organization”., dan Achua, “culture is the aggregate of beliefs, norms, attiuddes, values, assumptions, and ways of doing things that is shared by members of an organization and taught to new members".

Dalam rangka pemeliharaan budaya organisasi Slocum lebih lanjut menyatakan Indikator-indikator yang dapat menguatkan budaya organisasi, yakni (1) perhatian apa yang diberikan manajer dan tim kepada pengukuran dan pengendalian, (2) jalan dimana para manajer bereaksi untuk mengkritisi kecelakaan dan krisis organisasi, (3) peran permodelan, pembelajaran dan pelatihan manajemen dan tim (4) kriteria alokasi penghargaan dan status; 
(5) kriteria rekruiment, seleksi, promosi, dan pemindahan dari organisas dan (6) ritual, seremonial dan histori organisasi, sedangkan Dalam penguatan budaya organisasi, Schein dalam Nelson (2006:538) menyatakan bahwa, "leaders play crusial roles in shaping and reinforcing culture”. Lebih jauh, Gibson (2002), mengungkapkan bahwa, “A strong cultureis charaterized by employees sharing core values”.Budaya kuat dikarakteristikan oleh nilai-nilai inti bersama para anggota organisasi. Pada umumnya anggota berbagi dan menerima nilai inti bersama.Budaya yang lebih kuat adalah yang lebih mempengaruhi perilaku karyawan, organisasi yang religius, pemujaan-pemujaan.

Moeljono (2005), pengamatan para ahli dan pengalaman banyak praktisi manajemen menunjukkan bahwa (1) dalam organisasi yang budayanya kuat, perilaku para anggotanya dibatasi oleh kesepakatan bersama dan bukan karena perintah atau karena ketentuanketentuan formal, (2) dampak budaya yang kuat terhadap perilaku para anggotanya tampak besar dan telah berkaitan langsung dengan dengan menurunnya keinginan para anggota yang pindah berkarya di organisasi lain, dan (3), budaya yang kuat berarti akan makin banyak anggota organisasi yang menerima keterikatannya pada norma-norma dan sistem nilai-nilai tersebut.

Schein dalam Nelson (2006), membagi budaya dalam tiga tingkatan, yaitu “(1) artifact,(2) values, and (3) basic assumptions”. Artifact adalah hal-hal yang dilihat,didengar, dan dirasa kalau seseorang berhubungan dengan sebuah kelompok baru dengan budaya yang tidak dikenalnya, termasuk produk, jasa, dan bahkan tingkah laku anggota kelompok. Nilainilai (values) merupakan alasan bahwa orang berkorban demi yang dikerjakan. Budaya sebagian besar organisasi dapat melacak nilai-nilai yang didukung kembali ke penemu budaya, sedangkan asumsi dasar (basicassumptions) adalah keyakinan yang dianggap sudah ada oleh anggota organisasi.

Ketiga tingkatan budaya Schein tersebut membentuk pengertian dasar mengenai budaya organisasi.Budaya organisasi adalah perekat bagi setiap organisasi. Tanpa keberadaan budaya organisasi, maka sebuah organisasi akan mengalami proses pertumbuhan dan pemekaran tetapi tanpa diimbangi oleh integrasi dan reintegrasi. Oleh karena itu, tantangan dari setiap organisasi adalah pertama, memahami arti penting keberadaan budaya organisasi; kedua, membangun budaya organisasi dengan metode yang dapat diterima secara keilmuan, kemanusiaan, dan konteks keorganisasian; dan ketiga, senantiasa memelihara dan memperkuatnya. 
Dari berbagai deskripsi konsep yang dikemukakan oleh para ahli, dapat disintesiskan bahwa budaya organisasi adalah nilai-nilai, kepercayaan, dan norma-norma bersama yang dirasakan, dipikirkan, direnungi dan dianut serta kebiasaan yang dilakukan oleh seluruh anggota dalam organisasi dengan indicator; (1) nilai-nilai, kepercayaan, (2) aturan-aturan, (3) toleransi, (4) berorientasi hasil (outcomes), (5) perhatian pada orang, (6) bekerjasama, (7) perhatian pada tim kerja, (8) identitas, (9) stabilitas, dan (1) pola Komunikasi.

\section{Iklim Organisasi}

Perubahan lingkungan yang terjadi dengan cepat akan memaksa organisasi untuk selalu beradaptasi guna kelangsungan hidupnya dan menjadi dinamika kehidupan organisasi sehari-hari. Davis dan Newsstroom (1985) mendefinisikan iklim organisasi sebagai suasana lingkungan manusia dimana di dalamnya personil suatu organisasi melakukan pekerjaannya' Menurut Owen (1991) menyatakan, "organizational climate is the study of perceptions that individuals have of various aspects of the environment in the organization ".Iklim organisasi meliputi 3 (tiga) suasana, yakni (1) perhatian pada kegiatan akademis, (2) lingkungan yang kondusif, dan (3) harapan untuk berhasil. Iklim dapat juga dimaknai sebagai perasaan yang dibawa oleh individu ke dalam kelompok melalui tata ruang fisik dan cara baru

Berbagai definisi mengisyaratkan bahwa iklim organisasi memilki dua dimensi, yakni (1) persepsi, dan (2) lingkungan kerja. Individu menggunakan lima makna untuk memahami lingkungan melihat, menyentuh, mendengar, merasa, dan mencium. Persepsi membantu individu menyeleksi, mengatur, menyimpan, dan menginterpretasikan dorongan kedalam pemaknaan yang penuh arti dan gambaran yang padu tentang dunia.

Dalam pengukuran iklim organisasi, James dan Jones dalam Miskel dan Ogawa (1988)menjelaskan 3 (tiga) langkah pendekatan, yakni, “(1) multiplemeasurementorganizational atribut,(2) perceptual measurement-organizational atribute, and (3) perceptual measurement-invidual atribute”.Lebih jauh, Davis dan Newstroom (1985) menyatakan Iklim dapat berada di salah satu tempat pada kontinum yang bergerak dari yang menyenangkan ke yang netral sampai dengan yang tidak menyenangkan. Beberapa unsur khas yang turut membentuk iklim yang menyenangkan dalam suatu organisasi, yakni kualitas kepemimpinan, (2) kadar kepercayaan, (3) komunikasi, keatas dan ke bawah, (4) perasaan melakukan pekerjaan yang bermanfaat, (5) tanggung jawab Imbalan yang adil, (6) tekanan pekerjaan yang nalar, (7) kesempatan, (8) pengendalian, struktur, dan birokrasi nalar, (9) keterlibatan pegawai, keikut sertaan. 
Pada pengembangan iklim organisasi, Owen (1991) mengungkapkan bahwa, "the culture of an organization exert powerful influence on the development of climate".Meskipun budaya organisasi bersifat tidak berwujud, berpengaruh pada setiap kejadian-kejadian yang dirasakan para partisipan.Kondisi ini cukup menjelaskan bahwa budaya mempengaruhi sikap (attitut) dan perasaan para peserta (partisipan).

Halpin dan Croft dalam Owen (1991) memahami bahwa, "climate is the study of the perceptions of participants of factors in the organizational environment that arelikely to reflect the culture of the oragnization", dalam hal ini terdapat dua kluster faktor. Satu faktor berisikan empat faktor yang menjelaskan persepsi pendidik terhadap pendidik sebagai kelompok manusia, yaitu (1) Intimacy, (2) Disengagement, (3) Espirit, dan (4) Hindrance. Pada kluster lain dari faktor iklim merupakan persepsi kolektif perhatian para pendidik terhadap keutamaan, yakni (1) Thrust, (2) Consideration, (3) Aloofness, dan (4) Production emphasis.

Dalam pendapat lain, De Witte and De Cock dalam Sparrow (2001) menjelaskan, bahwa:

Climate represents a synthesis of perceptions about a relatively stable set of value orientations of the organization as a whole, which influence the behavior of the organizational members with respect to organizational effectiveness.

Hasil penelitian McMurray (2012) mengungkapkan bahwa, “leadership and climate are two organizational variables that are implicity linked".Kepemimpinan dan iklim merupakan 2 (dua) variabel yang secara implicit berhubungan. Lebih jauh hasil penelitian Koys dan DeCotiis dalam Mc Murray (2012) yang mengukur pengaruh kepemimpinan terhadap iklim pada organisasi non profit dengan 8 (delapan) dimensi, yaitu (1) kemandirian, (2) perhubungan (kohesi), (3) kepercayaan, (4) tekanan, (5) dukungan, (6) pengakuan, (7) keadilan, dan (8) dorongan pengedalian inovasi menunjukan penerimaan realibilitas konsistensi internal yang cukup signifikan pada skala alpha 0,80-0,89. Selanjutnya dengan menggunakan 6 (enam) dimensi, yaitu (1) kemandirian, (2) kepercayaan, (3) menunjukkan,(4) dukungan, (5) keadilan, dan (6) keinovatifan juga menunjukan hasil pengaruh positif yang cukup signifikan pada skala alpha 0,71-0,91.

Berdasarkan deskripsi konsep di atas, dapat disintesiskan iklim organisasi adalah suasana dari lingkungan kerja yang dirasakan, yang meliputi lingkungan fisik dan non fisik dalam organisasi, dan dibangun melalui hubungan staf dan hubungan atasan-bawahan, dengan 
indicator; (1) hubungan, (2) dukungan, (3) tekanan pekerjaan, (4) pengakuan, (5) loyalitas, (6) saling mempercayai, (7) saling bekerjasama, dan (8) saling toleransi.

\section{METODOLOGI PENELITIAN}

Penelitian menggunakan pendekatan kuantitatif, metode survey dengan analisis jalur (path analysis). Instrumen penelitian, terdiri dari; (1) 55 butir pernyataan valid atas variabel tata kelola, dengan koefisen reliabilitas (Alpha Cronbach) sebesar 0,929, (2) 66 butir pernyataan valid atas variabel kepemimpinan, dengan koefisen reliabilitas (Alpha Cronbach) sebesar 0,971 (3) 69 butir pernyataan valid atas variabel budaya organisasi dengan koefisen reliabilitas (Alpha Cronbach) sebesar 0,951, dan (4) 50 butir pernyataan valid atas variabel iklim organisasi, dengan koefisen reliabilitas (Alpha Cronbach) sebesar 0,952 yang diajukan kepada 251 (dua ratus lima puluh satu ) dosen selaku responden pada 109 program studi perguruan tinggi swasta di Kota Pekanbaru sebagai sampel. Teknik analisis data dilakukan dalam dua tahap, yaitu secara deskriptif dan inferensial. Penyajian data deskriptif menggunakan daftar distribusi, histogram, ukuran sentral (mean, median dan modus), dan ukuran penyebaran (varian dan simpangan baku). Analisis inferensial digunakan untuk menguji persyaratan dan hipotesis dengan menggunakan analisis jalur (path analysis). Semua pengujian persyaratan analisis dan hipotesis dilakukan dengan menggunakan nilai $\alpha=0,05$ dan 0,01. Persyaratan analisis mencakup (1) normalitas galat taksiran dengan teknik Liliefors, dan (2) signifikansi dan linieritas regresi dengan menggunakan statistic F test.

\section{PEMBAHASAN}

\section{Hasil Penelitian}

Penelitian ini dimaksud untuk mengukur empat variabel yaitu, Tata Kelola $\left(\mathrm{X}_{4}\right)$, Kepemimpinan $\left(\mathrm{X}_{1}\right)$, Budaya Organisasi $\left(\mathrm{X}_{2}\right)$, dan Iklim Organisasi $\left(\mathrm{X}_{3}\right)$, yang dilakukan pada 251 responden. Masing-masing variabel diukur secara terpisah melalui instrumen penelitian yang dibuat dalam bentuk pernyataan yang menggunakan skala pengukuran Likert dengan lima alternatif jawaban yang tersedia.

Skor deskriptif data penelitian untuk keempat variabeltata kelola, kepemimpinan, budaya organisasi, dan iklim organisasi secara keseluruhan berada dalam peringkat sedang. Hasil pengujian persyaratan data normalitas galat taksiran atas keenam hipotesis menunjukkan bahwa data sampel berasal dari populasi yang berdistribusi normal, dan hasil uji Signifikansi dan Linieritas Koefisien Regresimenunjukkan hubungan kelima hipotesis yang sangat signifikan pada $\alpha=0,05$, dan berbentuk linier. 
Berdasarkan perhitungan dan pengujian koefisien jalur, diperoleh hasil pengaruh antar variabel kelima hipotesis, sebagaimana terdapat pada tabel 1, berikut ini.

Tabel1

Hasil Perhitungan dan Pengujian Koefisien Jalur $(\rho)$

\begin{tabular}{|c|c|c|c|c|l|}
\hline \multirow{2}{*}{ Jalur } & \multirow{2}{*}{$\begin{array}{c}\text { Koefisien } \\
\text { Jalur }\end{array}$} & \multirow{2}{*}{$\mathrm{t}_{\text {hitung }}$} & \multicolumn{2}{|c|}{$\mathrm{t}_{\text {tabel }}$} & \multirow{2}{*}{ Keterangan } \\
\cline { 4 - 5 } & & $\alpha=0,05$ & $\alpha=0,01$ & \\
\hline $\mathrm{p}_{41}$ & 0,15 & 3,26 & 1,64 & 2,33 & Sangat signifikan pada $\alpha=0,05$ \\
\hline $\mathrm{p}_{42}$ & 0,48 & 6,99 & 1,64 & 2,33 & Sangat signifikan pada $\alpha=0,05$ \\
\hline $\mathrm{p}_{43}$ & 0,26 & 3,79 & 1,64 & 2,33 & Sangat signifikan pada $\alpha=0,05$ \\
\hline $\mathrm{p}_{31}$ & 0,12 & 2,86 & 1,64 & 2,33 & Sangat signifikan pada $\alpha=0,05$ \\
\hline $\mathrm{p}_{32}$ & 0,77 & 18,85 & 1,64 & 2,33 & Sangat signifikan pada $\alpha=0,05$ \\
\hline
\end{tabular}

Pada Tabel 1 di atas dapat diketahui bahwa hasil uji empirik menunjukkan bahwa koefisien jalur sangat signifikan yang diindikasikan dengannilai $t_{\text {hitung }}$ lebih besar dari $t_{\text {tabel }}$ pada taraf $\alpha=0,05$ dan $\alpha=0,01$, sehingga sehingga kelima hipotesis alternatif $\mathrm{H}_{1}$ diterima dan $\mathrm{H}_{\mathrm{o}}$ ditolak.

\section{Pembahasan Hasil Penelitian}

Berdasarkan hasil analisis dan pengujian hipotesis menunjukkan keenam hipotesis yang diajukan dalam penelitian ini terbukti, yaitu (1) kepemimpinan berpengaruh langsung positif terhadap tata kelola, (2) budaya organisasi berpengaruh langsung positif terhadap tata kelola, (3) iklim organisasi berpengaruh langsung positif terhadap tata kelola, (4) kepemimpinan berpengaruh langsung positif terhadap iklim organisas, dan (5) budaya organisasi berpengaruh langsung positif terhadap iklim organisasi,

\section{Pengaruh Langsung Positif Kepemimpinan Terhadap Kelola}

Hasil penelitian menunjukkan kepemimpinan berpengaruh langsung positif terhadap tata kelola. Hal ini menjelaskan semakin kuat kepemimpinan, maka menjadikan tata kelola semakin baik.Kepemimpinan adalah seni mempengaruhi orang lain dalam mencapai tujuan organisasi. Selanjutnya, dalam pencapaian suatu tujuan organisasi diperlukan proses tata kelola yang baik dengan penerapan praktek-praktek yang sehat (best practice). Tata kelola (governance) adalah prosedur dan proses yang mengarahkan dan mengendalikan organisasi, melalui proses hubungan antara pengurus ataupun dengan para pihak berkepentingan lainnya, guna untuk pencapaian stratejik organisasi secara optimal. 
Pola hubungan yang dibangun dalam proses tata kelola menunjukkan adanya pengaruh antara kepemimpinan dengan tata kelola program studi, sebagaimana yang dikemukakan oleh Yukl (2010) Most definition of leadership reflect the assumption that involves a process whereby intentional influence is exerted over other people to guide, structure, and facilitate activities and relationships in a group or organization. Pendapat YukL tesebut menjelaskan kepemimpinan merupakan suatu proses mempengaruhi orang lain untuk mengarahkan, membentuk dan memfasilitasi aktivitas-aktivitas dan hubunganhubungan dalam suatu organisasi. Selanjutnya diperkuat oleh Gibson, et.al (2002), "leadership as an interaction between members of a group". Lebih jauh pola hubungan merupakan persyaratan dalam pemenuhan tata kelola yang baik sebagaimana yang diungkapkan oleh Shattock (2006), tata kelola "as the constitutional forms and processes through which universities govern their affairs".

Dalam mengarahkan pencapaian tujuan organisasi Nelson (2006) menyatakan,” Leadership in organization is the process of guiding and directing the behavior of people in the work environment”.Ketua program studi selaku pimpinan memberikan arah pencapaian tujuan, dan mengambil keputusan berazaskan prinsip tanggung jawab dan partisipasi. Hal ini tercermin, antara lain dari tindakan ketua program studi melakukan coaching kebijakan baru, dan mensosialisasikan laporan kegiatan secara berkala kepada dosen.

Hasil penelitian Mortimer dan Mc.Connel (2007) menjelaskan dalam proses tata kelola akademik, antara lain terdapat kebijakan sharing of authority. Pendelegasian wewenang merupakan konsep pembagian wewenang yang menekankan hubungan timbal balik dan saling ketergantungan antara pemilik internal, satuan tugas tata kelola, fakultas, pejabat pengelola dan mahasiswa.Dalam pendelegasian wewenang Ketua program studi, antara lain memberikan tugas sesuai dengan keahlian yang dimiliki dosen, dan menunjuk dosen yang berwenang menghadiri pertemuan-pertemuan dengan pihak internal ataupun dengan eksternal. Selain itu, terdapat hasil penelitian yang dilakukan oleh Wakansagalu (2012), yang menyimpulkan perilaku pemimpin dapat mempengaruhi tata kelola yang baik, dan pimpinan yang baik harus mengimplementasikan transparansi, dan partisipisi dalam semua tindakan kepada para anggota organisasinya. Selanjutnya, penelitian yang dilakukan oleh Widiastuti (2013) terdapat pengaruh gaya kepemimpinan terhadap tata kelola dengan loading factor sebesar 2,54. 
Untuk mewujudkan pencapaian visi program studi secara maksimal diperlukan seorang pemimpin yang mempunyai kuasa (power) dalam mempengaruhi para bawahan. Kuasa adalah esensi kepemimpinan dalam aktivitas mempengaruhi sebagaimana yang kemukakan oleh Wirawan (2003). Kuasa seorang pemimpin diukur seberapa besar pengaruh pemimpim dalam memberikan imbalan, memberikan sanksi, dan keahlian serta kepribadian yang dimilikinya. Indikator kuasa ini mencapai hasil yang maksimal, karena dalam pengelolaan program studi dilaksanakan tata kelola yang baik, yaitu kebijakan dan partisipasi yang konsisten dan dapat diterima secara umum serta mengutamakan keseimbangan yang mengacu pada komitmen organisasi untuk mengimplentasikan kebijakan dan peraturan-peraturan.

\section{Pengaruh Langsung Positif Budaya Organisasi Terhadap Tata Kelola}

Hasil penelitian menunjukkan budaya organisasiberpengaruh langsung positif terhadap tata kelola. Hal ini menjelaskan semakin kuat budaya organisasi, maka menjadikan tata kelola semakin baik.Budaya organisasi dalam suatu program studi secara operasional mencerminkan nilai-nilai, kepercayaan, dan norma-norma bersama yang dirasakan, dipikirkan, direnungi dan dianut serta kebiasaan yang yang dilakukan oleh seluruh anggota organisasi Mc Shane (2008) menjelaskan: Consists of the values and assumptions shared within an organization. It defined what is important and unimportant in the company and consequently directs everyone in the organization toward the right way of doing things.

BAN-PT menyatakan, bahwa: Tata pamong (governance) didukung dengan budaya organisasi yang dicerminkan dengan tegaknya aturan, etika dosen, etika mahasiswa, etika tenaga pendidikan, sistem penghargaan dan sanksi serta pedoman dan prosedur pelayanan (administrasi, perpustakaan, laboratorium, dan studio) harus diformulasi, disosialisasikan, dilaksanakan, dan dievaluasi dan dipantau dengan peraturan dan prosedur yang jelas.

Hasil penelitian Rafiee dan Sarabden (2012) menjelaskan, “states culture influences the organizational policies through the values held by decision makers".Budaya bangsa mempengaruhi kebijakan-kebijakan organisasi melalui nilai-nilai pembuat keputusan.Hal ini mengandung makna bahwa budaya mempengaruhi tata kelola dalam indikator kebijakan, dimana ketentuan-ketentuan yang dibuat oleh pengambil keputusan mengandung nilai-nilai yang dapat diterima secara umum dan menguatkan keseimbangan.Selanjutnya Rafiee dan Sarabden memberikan saran, "culture contributes to the interpersonal relationship of individuals and institutions relationships and consequently changes the choice of corporate 
governance structure. Saran ini memperjelas terdapat hubungan antara budaya dengan tata kelola, dimana budaya memberikan kontribusi dalam hubungan antar individu dan organ organisasi, dan memberikan perubahan yang konsekwen dalam pilihan struktur tata kelola korporasi.Selain itu, hasil penelitian Prasetyo (2013) diperoleh hasil terdapat pengaruh budaya organisasi dengan tata kelola, yang tercermin pada indikator partisipasi.

Keberhasilan penerapan tata kelola program studi didukung dengan terciptanya suatu suasana lingkungan kerja yang kondusif diantara dosen, staf pendukung dan mahasiswa dalam bentuk adanya kebebasan (independensi) yang diberikan kepada setiap individu untuk berinisitif dalam melakukan tindakan pekerjaan, perhatian yang diberikan oleh manajer kepada orang dan tim kerja yang dibentuk serta toleransi-toleransi yang seimbang terhadap risiko yang terjadi dalam setiap tindakan yang sulit dikendalikan. Hal ini sejalan dengan indikator tata kelola kemandirian dan tanggung jawab, yaitu setiap individu harus bebas dari pengaruh-pengaruh dan tekanan dari pihak manapun, dan pimpinan berpartisipasi terhadap keberhasilan organisasi.

\section{Pengaruh Langsung Positif Iklim Organisasi Terhadap Tata Kelola}

Hasil penelitian menunjukkan iklim organisasiberpengaruh langsung positif terhadap tata kelola. Hal ini menjelaskan semakin kondusif iklim organisasi, maka menjadikan tata kelola semakin baik. Schneider and Rentsch dalam Agarwal and Malloy (1989) menyarankan bahwa, "climate is the message that organizational members receive from organizational policies, procedures, and reward system”.Pengertian iklim organisasi tersebut pada dasarnya mengandung makna bahwa prosedur dan sistem dalam suatu organisasi merupakan alat dalam mencapai tujuan. Hal ini, sejalan dengan dengan makna tata kelola sebagaimana yang dikemukakan oleh OECD, yaitu "procedures and processes according to wich an organization is directed and controlled”.

Pesan yang diterima oleh anggota dan persepsi bersama atas kebijakan, pelaksanaan dan prosedur organisasi tersebut menunjukkan adanya hubungan, pengakuan, dan loyalitas yang berkaitan dengan indikator tata kelola transparansi, keadilan, tanggung jawab, dan partisipasi, dimana adanya adanya perlakuan yang setara terhadap semua pihak yang berkepentingan sesuai dengan kriteria dan proporsi yang seharusnya.

Indikator hubungan, antara lain ditunjukkan dari sesama dosen saling memberikan apresiasi verbal atas keberhasilan yang diperoleh dalam kegiatan tridharma perguruan tinggi. Indikator pengakuan ditunjukkan, antara lain ditunjukkan dari program studi memberikan 
penghargaan dalam bentuk penjenjangan karir bagi dosen yang emnunjukkan prestasi di bidang proses belajar mengajar. Indikator loyalitas, ditunjukkan darikomitmen yang tinggi dalam melaksanakan tugas yang ditunjukkan dosen dalam sikap keseharian.

Pengaruh antara iklim organisasi dan tata kelola diperkuat oleh Sparrow (2001:89), yang menyatakan: The perceptions that climate instruments tap are principally practice and procedures that evidence such policies, the goals the policies are intended to serve, and the perceived derived from the formal and informal organizational policies, the means of attainment.

\section{Pengaruh Lansung Positif Kepemimpinan Terhadap Iklim Organisasi}

Hasil penelitian menunjukkan kepemimpinanberpengaruh langsung positif terhadap iklim organisasi. Hal ini menjelaskan semakin kuat kepemimpinan, maka menjadikan semakin kondusif iklim organisasi. Iklim organisasi secara operasional mencerminkan suasana dari lingkungan kerja yang menggambarkan keseluruhan lingkungan fisik dan non fisik dalam organisasi, sedangkan kepemimpinan adalah seni mempengaruhi orang lain untuk mencapai tujuan organisasi. Dalam rangka mencapai tujuan organisasi diperlukan suasana lingkungan kerja yang kondusif.

Ketua program studi mempengaruhi segenap anggota organisasi dalam bentuk penciptaan suasana lingkungan kerja yang kondusif melalui keteladanan perilaku, keahlian manajerial yang dimiliki, pemberian dan pendelegasian wewenang yang sesuai dengan standar yang disepakati serta memberikan imbalan dan saksi sesuai dengan prinsip kesimbangan dan keadilan. Implementasi indikator-indikator kepemimpinan ini secara langsung akan menciptakan suatu hubungan yang harmonis diantara para anggota, dukungan dan pengakuan yang dirasakan oleh setiap individu yang selanjutnya berdampak pada meningkatnya loyalitas, saling mempercayai dan saling bekerjasama para anggota dalam pencapaian tujuan organisasi.

Hasil penelitian McMurray (2012) mengungkapkan, “leadership and climate are two organizational variables that are implicity linked". Selanjutnya Iklim organisisasi dapat didefinisikan sebagai, "the share perceptions of organizational policies, practice, and procedures". Lebih jauh hasil penelitian Koys dan DeCotiis dalam Mc Murray yang mengukur pengaruh kepemimpinan terhadap iklim pada organisasi non profit dengan 8 (delapan) dimensi, yaitu (1) kemandirian, (2) perhubungan (kohesi), (3) kepercayaan, (4) tekanan, (5) dukungan, (6) pengakuan, (7) keadilan, dan (8) dorongan pengendalian inovasi 
menunjukan penerimaan realibilitas konsistensi internal yang cukup signifikan pada skala alpha 0,80-0,89. Selanjutnya dengan menggunakan 6 (enam) dimensi, yaitu (1) kemandirian, (2) kepercayaan, (3) menunjukkan, (4) dukungan, (5) keadilan, dan (6) keinovatifan juga menunjukan hasil pengaruh positif yang cukup signifikan pada skala alpha 0,71-0,91.

Hasil penelitian Yildiz and Ozcan (2014), menjelaskaniklim organisasi membawa pengaruh penentu dalam hubungan antara kepemimpinan transformasional dan krestivitas anggota organisasi. Selain itu, hasil penelitian Emilia dan Syamsir (2011) pada PT. PLN Cabang Solok, mengungkapkan terdapat pengaruh langsung positif antara gaya kepemimpinan terhadap iklim kerja organisasi. Iklim organisasi ditafsirkan sebagai kualitas interaksi antara sesama anggota organisasi dalam bingkai kerjasama internal untuk memberikan pelayanan terbaik terhadap segenap pemangku kepentingan organisasi, baik pihak-pihak internal seperti mahasiswa, dosen, pegawai maupun eksternal seperti dunia kerja, industri dan masyarakat.Iklim organisasi diciptakan oleh pemimpin organisasi bersama seluruh anggotanya.

\section{Pengaruh Lansung Positif Budaya Organisasi Terhadap Iklim Organisasi}

Hasil penelitian menunjukkan budaya organisasiberpengaruh langsung positif terhadap iklim organisasi. Hal ini menjelaskan semakin kuat budaya organisasi, maka menjadikan iklim organisasi semakin kondusif. Nelson (2006), antara lain menyatakan ” cultures provides a sence of identity to members and increases their commitment to the organization".

Hasil penelitian Walles, Hunts and Richards dan Ekvall dalam Yildiz and Ozcan (2014), menyimpulkan Iklim organisasi dan budaya organisasi saling mempengaruhi satu sama lain, namun iklim organisasi tidak identik dengan budaya organisasi. Budaya mengacu pada kedalaman nilai-nilai, norma-norma dan kepercayaan dalam organisasi, sedangkan iklim organisasi berbeda dari budaya yang dapat diamati secara langsung dalam organisasi.

Budaya organisasi yang kuat tergambar dari perhatian yang diberikan oleh manajer kepada setiap individu dan tim kerja, dilaksanakannya aturan-aturan yang dikarekteristikan oleh nilai-nilai inti bersama oleh para anggota organisasi. Hal ini secara langsung akan mempengaruhi terciptanya suasana iklim organisasi yang kondusif yang terlihat pada indikator dukungan dan loyalitas. Selain itu, terciptanya kepercayaan, dan pola komunikasi dalam suatu budaya organisasi akan dapat meningkatkan suatu hubungan yang lebih kuat, 
pengakuan dan loyalitas serta saling mempercayai yang lebih tinggi dalam suatu lingkungan iklim organisasi.

\section{Kesimpulan}

Berdasarkan hasil dari analisis data dan pembahasan hasil penelitian, disimpulkan bahwa: (1) kepemimpinan berpengaruh langsung positif terhadap tata kelola. Hal ini menunjukkan peningkatan kepemimpinan yang kuat berpengaruh langsung terhadap peningkatan tata kelola yang baik., (2) budaya organisasi berpengaruh langsung positif terhadap tata kelola. Hal ini menunjukkan peningkatan budaya organisasi yang kuat berpengaruh langsung terhadap peningkatan tata kelola program studi yang baik, (3) Iklimorganisasi berpengaruh langsung positif terhadap tata tata kelola. Hal ini menunjukkan peningkatan iklim organisasi yang kondusif berpengaruh langsung terhadap peningkatan tata kelola yang baik, (4) Kepemimpinan berpengaruh langsung positif terhadap iklim organisasi. Hal ini menunjukkan peningkatan kepemimpinan yang kuat berpengaruh langsung terhadap peningkatan iklim organisasi yang kondusif, dan (5) Budaya organisasi berpengaruh langsung positif terhadap iklim organisasi. Hal ini menunjukkan peningkatan budaya organisasi yang kuat berpengaruh langsung terhadap peningkatan iklim organisasi yang kondusif,

\section{Saran}

Berdasarkan kesimpulan dan implikasi hasil penelitian, disarankan langkah-langkah tindak lanjut, sebagai berikut:

1. Untuk meningkatkan kepemimpinan program studi yang kuat, Ketua Program Studi: (1) menghormati keterbatasan yang dimiliki dosen, (2) melibatkan para bawahan dalam penyelesaian masalah, (3) dalam melaksanakan semua tindakan berorientasi pada hasil yang lebih baik, (4) menciptakan keharmonisan dalam hubungan sosial secara vertikal, (5) melakukan evaluasi kinerja secara berkala,(6) memberikan bantuan fasilitasi kepada institusi terkait bagi dosen dalam rangka melaksanakan kegiatan pengabdian masyarakat, (7) menyusun laporan kinerja pertanggung jawaban yang transparan, (8) bertindak bebas dari pengaruh para pihak dalam pengambilan keputusan, dan (9) dalam melaksanakan pekerjaan menunjukkan tanggung jawab yang besar.

2. Untuk meningkatkan budaya organisasi program studi yang kuat:(1) program studi melimpahkan wewenang sesuai dengan keahlian dan tanggung jawab dosen, (2) 
program studi menetapkan ketentuan dan kebijakan tertulis dalam semua tindakan dan kegiatan pekerjaan, (3) kebijakan program studi disosialisasikan kepada seluruh dosen, (4) program studi menetapkan batas toleransi kesalahan dosen dalam proses belajar-mengajar, (5) program studi membebaskan dosen melakukan kegiatan belajar mengajar selama mengikuti pendidikan yang lebih tinggi, (6) program studi menetapkan batas tenggang waktu tambahan dalam penyelesaian kegiatan penelitian (7) program studi membentuk satuan tugas dalam merumuskan perencanaan stratejik, (8) program studi mendorong dosen untuk menunjukkan semangat kekeluargaan dalam melaksanakan pekerjaan, dan(9) nilai-nilai budaya yang dianut program studi dikomunikasikan kepada seluruh stakeholders secara berkelanjutan.

3. Untuk meningkatkan iklim organisasi program studi yang kondusif: (1), program studi menyediakan sarana proses belajar mengajar yang memadai, (2) program studi menyediakan prasarana proses belajar mengajar yang memadai, (3) program studi mencari dana mitra sebagai dukungan dalam penelitian dosen, (4) program studi mencari dana mitra sebagai dukungan dalam peningkatan kualitas kegiatan pengabdian masyarakat dosen, (5) program studi memberikan piagam penghargaan dalam periode tertentu terhadap dosen yang menunjukkan komitmen pengabdian, (6) program studi memberikan penghargaan dalam bentuk bea siswa untuk mengikuti pendidikan yang lebih tinggi bagi dosen yang telah menunjukkan inovasi di bidang kelimuan masing-masing, dan (7) perumusan perencanaan stratejik p I studi melibatkan pimpinan dan para dosen.

\section{REFERENSI}

Achua Christopher F and Lussier Robert N, Effective Leadership, Canada: South Western,2010

Arief Effendi.Muh, The Power of Corporate Governance, Teori dan Implementasi, Jakarta: Salemba Empat, 2009

BAN-PT, Akreditasi Program Studi Sarjana, Buku VII Pedoman Asesmen Lapangan, Jakarta: Badan Akreditasi Nasional Perguruan Tinggi, 2008.

BPKP, Tim Corporate Governance, Dasar-dasar Corportae Governance Jakarta: Deputi Bidang Akuntan Negara selaku Penangung jawab Tim Corporate Governance BPKP, 2003 
Daft Richard L, New Era of management, Australia: South Western- Cengage Learning, $9^{\text {th }}$ Edition, 2010

\section{----------The Leadership Experience, Canada: South Western, 2005}

Davis Keith and Newsstroom Jhon, Perilaku Dalam Organisasi. Jakarta: Erlangga, Edisi ketujuh, 1985

Dewi Kartika Sari, Hubungan Antara Iklim Organisasi danOrganizational Citizenship Behavior, Semarang: Unika Prihatsanti

Edwards Meredith, University Governance: A Mapping and Some Issues, Life Long Learning Network national Conference

Emilia Suci, Syamsir, Pengaruh Gaya Kepemimpinan Terhadap Iklim Kerja Organisasi pada PT.PLN Cabang Solok, Demokrasi, Vol X, No.2,Tahun 2011, h.171.

Eurydice, Higher Education Governance in EuropePolicies, structures, funding and academic Staf Eurydice.Brussel:2008

Gibson James L. et.al, Organization, Behavior, Structures and Process Singapore: McGraw Hill, Irwin, $11^{\text {th }}$ Edition, 2002

Gelade Garry, Gilbert Patrick, Work Climate and Organizational Effectiveness Published: SAGE Publications, Organizational Research Methods, Vol. 6 No.4, 2003

Hopkin. R. Bruce, Gross.C.Virginia, Non Profit Governance, Law Practice and Trend, New Jersey: Jhon Wiley \& Sons, 2009

House J.Robert, et,al, Cultural Influence on Leadership and Organization: Project Globe, University of Zurich,2013,h.70.

Indrajit R.Eko, Pranoto,R. Djoko Manajemen Perguruan Tinggi Modern Yogyakarta: CV. Andi Ofset, 2006

International Fund For Agricultural Development (IFAD) UNDP, Good Governance: An Overview,

Kamanto dan Brodjonegoro,Daya Saing SDM, hht://manto.undip.ac.id (diakses tanggal 15 Mei 2013)

Koentjaraningrat,Pengantar Ilmu Antropologi. Jakarta: PT.Rineka Cipta, 1990

Laughlin. L Fred, Andringa.C Robert, Good Governance For Non Profit, Developing Principles and Policies For an Effective Board, New York:Amacom,2007

McShane Stephen L, Von Glinow Mary Ann, Organizational Behavior. New York: McGraw Hill, $4^{\text {th }}$ Edition,2008 
McMurray A.J. et.al, The Impact of Leadership on Work Group Climate snd Performance in aNon- Profit Organization, Organization Development Journal, Vol 33 No. 6 , 2012

Moeljono Djokosantoso, Culture, Budaya Organisasi Dalam Tantangan. Jakarta: PT. Elex Media Komputindo, 2005

Mortimer Kenneth P, McConnell T.R, Process of Academic Governance Jossey Bass Inc Publisher, ASHE Reader on Organization and Governance

Mullins,Laurie J, Management and Organizational Behavior.Edinberg, England: Prentice Hall, 2010

National Commission on Human Right, Good Governance and Civil Society, Bandung: Sanic Offset, 2000

Nelson Debra L, Quick James Campbel, Organizational Behavior. Mason Ohio: South Western, $5^{\text {th }}$ Edition, 2006

Newstroom John W, Davis Keith, Organizational Behavior, Human Behavior at Work. New York: Mc Graw Hill, Irwin, $11^{\text {th }}$ Edition, 2002

OECD, Definition, European Cental Bank, 2004, http://www.oecd.org (diakses tanggal 6 Juni 2013)

Owen Robert.G, Organizational Behavior in Education. Needham Heihgt MA:Prentice Hall, $4^{\text {th }}$ Edition,1991

Peraturan Pemerintah Nomor. 19 Tahun 2005, tentang Standar Nasional Pendidikan

Robbins Stephen P, Organizational Behavior. New Jersey: Pearson Education.Alnc Publissing as Prentice Hall, $14^{\text {th }}$ Editon,2011

Prasetyantoko. A, Corporate Governance, Pendekatan Institutional, Jakarta: Bina Aksara,2012

Prasetyo Hanung Nindito, Analisis Budaya Organisasi Pada Rancangan Tata kelola Data di perguruan Tinggi X, Seminar Nasional Sistem Informasi Indonesia, 2-4 Desember, h. 8

Shein Edgar H, Organizational Culture and Leadership, San Francisco: Jossey-Bass, 2010

Schemerhon Jhon, Introduction to Management, Hoboken: Jhon Wiley and Sons Pte Limited, 2010

Shattock Michael, Managing Successful Universities . New York: Open University Press, 2003 -Managing Good Governance in Higher Education. Open University Press, 2006 
Singarimbun Masri, Metode dan Proses Penelitia, dalam Masri Singarimbun dan Sofian Efendi (eds). Metode Penelitian Survai .Jakarta:LP3ES,1989

Slocum Jhon W Jr, Helieriegel Don, Principles of Organizational Behavior.China: South Western, $12^{\text {th }}$ Edition, 2009

Sparrow Paul R, Developing Diagnostics For High Performance Organization Cultures, dalam The International Handbook of Organizational Culture and Climate, Chichester, England: John Wiley \& Sons Ltd, 2001

Sudarmanto R.Gunawan, Good University Governance, Pemahaman, Pengertian dan Bagaimana Seharusnya Implikasi Dalam Penyelenggaraan Perguruan Tinggi, hhtp://blog.unila.ac.id/ radegunawans/files (diakses tanggal 4 Maret 2013).

Sutojo Siswanto, Aldridge E John, Good Corporate Governance, Tata Kelola Perusahaan Yang Sehat .Jakarta: PT. Damar Mulia Pustaka, 2005

Sugiyono, Statistika Untuk Penelitian Bandung: Penerbit Alfabeta, 2010

Sutedi Adrian, Good Corporate Governance, Jakarta: Sinar Grafika,2012

The Carnegie Foundation For The Advancement of Teaching, From The Campus A Report on The Governance of Higher Education, Princeton University Press dalam ASHE Reader on Organization Governance in Higehr Education Lexingto, Massachusset: Ginn Press, $3^{\text {rd }}$ Edition

Undang-undang No 12 Tahun 2012, Tentang Pendidikan Tinggi .

Vahideeh Rafiee, Jawahitha Sarabden, The Cutural Influence in The Practice Corporate Governance in Emerging Market, IBIMA, Vol.2012, h.7

Wakasangalu Eliza, et,al, The Infulence of Leadership on Good Governance: The Case of Selected Village in Rungwe and Babati Distric Council in Tanzania (Netherland: School Public Adminstration, 2012) h,50.

Widiastuti Sri, Dampak Penerapan Tata Kelola Perusahaan Yang Baik Terhadap Kinerja Bank Umum Syariah (Jakarta: Fakultas Ekonomi Universitas Pancasila, 2013), h.18.

Yildiz Muge Leyle, Ozcan Esra Dinc, Organizational Climate as a Moderator of The Relationship between Transformational Leadership and Creativity, International Journal of Business and Management, Vol.II (1), 2014, h.84.

Yukl Gary, Leadership in Organization. New Jersey: Pearson Prentice Hall, $7^{\text {th }}$ Edition,2010 